\title{
Instituições e desenvolvimento no Japão: modelo de capitalismo, trajetória pós 1990, desafios atuais
}

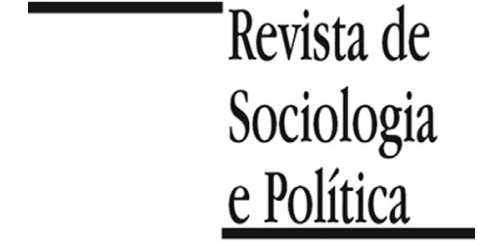

DOI 10.1590/1678-987316246002

\author{
Alexandre Queiroz Guimarães, André Mourthé de \\ Oliveira, Rafael Teixeira Dias Camargo e \\ Paulino Oliveira Neto
}

\section{Resumo}

O objeto principal do artigo é a mudança de trajetória do capitalismo japonês, procurando entender por que um modelo tão bem-sucedido nas décadas de 1950 a 1980 passou a enfrentar sérias dificuldades a partir dos anos 1990. Para isso, trabalha a interação entre fatores institucionais, econômicos e políticos, dando atenção especial às instituições típicas do capitalismo japonês, incluindo as relações de trabalho, a governança corporativa, a organização do sistema financeiro e o papel do Estado. Procura-se destacar o papel que essas instituições tiveram na fase de prosperidade e também as pressões que passaram a sofrem a partir das mudanças domésticas e internacionais. Um aspecto central é interpretar até que ponto o modelo japonês continua distintivo, preservando as características de um "modelo de capitalismo coordenado". O artigo adota um enfoque de economia política centrado nas teorias do institucionalismo histórico e das variedades de capitalismo. Essas teorias, ao mostrar como as instituições nacionais condicionam o padrão de resposta, fornecem um invólucro para interpretar as mudanças, ampliando a compreensão das interações entre economia, política e instituições. A partir do referencial mais geral, o artigo incorpora também teorias mais específicas voltadas a interpretar a crise econômica e alguns desafios enfrentados pela economia japonesa. O artigo mostra que o Japão vem passando por muitas mudanças institucionais, mas vem também preservando aspectos distintivos do modelo tradicional japonês, com a constituição de um modelo híbrido. Além dos problemas macroeconômicos, ligados à insuficiência de demanda efetiva, ao envelhecimento da população e aos desafios fiscais, há também muitos desafios sociais e políticos, que incluem a forte dualidade no mercado de trabalho e as dificuldades enfrentadas por jovens e mulheres. Em face de todas essas questões, o sistema político vem falhando em oferecer um pacote alternativo de reformas. Em síntese, ao explorar e combinar diversas dimensões, o artigo contribui para compreender muitos dos desafios enfrentados pela economia e pela sociedade japonesa.

PALAVRAS-CHAVE: variedades de capitalismo; instituições; Japão; Economia Política comparada; desenvolvimento comparado.

Recebido em 15 de Maio de 2015. Aceito em 23 de Julho de 2015.

\section{Introdução ${ }^{1}$}

\footnotetext{
1 Agradecemos aos pareceristas anônimos da Revista de Sociologia e Política por seus comentários. Agradecemos também ao Fundo de Incentivo à Pesquisa da PUC-MG e à Coordenação de Aperfeiçoamento de Pessoal de Nível Superior (Capes). O apoio da Capes foi essencial para a redação da versão atual do artigo.
}

$\mathrm{O}$ objetivo deste artigo é analisar a trajetória recente do modelo econômico japonês, enfatizando o papel de fatores econômicos, políticos e institucionais. Nas três décadas que se seguiram à II Guerra Mundial, a economia japonesa avançou significativamente, dando saltos na produtividade e nas exportações e se transformando na segunda maior economia do mundo. Desenvolveu um modelo particular de capitalismo, destacado por muitos como uma das razões do sucesso. No entanto, a partir dos anos 1990 o Japão passou a enfrentar uma das mais resilientes crises da história do capitalismo. Ainda hoje, mais de duas décadas depois, o Japão enfrenta sinais de dificuldades e de estagnação.

A inflexão na trajetória japonesa e sua longa crise colocam importantes questões para o estudo da economia comparada: como pode a situação de um país mudar tão drasticamente? Como as instituições que tanto contribuíram para o sucesso anterior transformaram-se em componentes da estagnação sub- 
sequente? Por que o sistema político não apresentou direções para que o modelo se renovasse e se recuperasse? Por que é tão difícil modificar instituições e práticas? O que o Japão precisa fazer para se recuperar?

O objetivo deste artigo é aprofundar essas questões e investigar o rumo que vem sendo seguido pelo capitalismo japonês. Mudanças profundas foram engatilhadas pela internacionalização e pelas novas configurações da economia mundial. Outras mudanças foram decorrentes de transformações na estrutura econômica e nos interesses políticos, tendo sido a crise um importante catalizador. O artigo procura observar as instituições à luz das mudanças econômicas e internacionais. Uma questão central é se o modelo japonês será capaz de preservar as suas instituições ou se, em face das novas tendências, as suas características institucionais perderão relevância.

Para isso, o artigo adota uma abordagem muito influenciada pelos approaches do institucionalismo histórico e dos modelos de capitalismo (Hall \& Soskice 2001). Ao relacionar economia, política e instituições, procura entender a trajetória do modelo japonês e suas respostas e adaptação às mudanças. Para esse intuito, a seção II enfatiza os fatores institucionais responsáveis pelo sucesso japonês no período de 1950 a 1973. A seção III explora a mudança de regime, mostrando como o arranjo construído no pós-guerra se modificou, e suas implicações. A seção aborda também aspectos da crise da década de 1990 e as principais dificuldades para enfrentá-la. A seção IV explora os desafios e as mudanças que vêm ocorrendo no modelo de governança corporativa e no sistema financeiro. A seção $\mathrm{V}$ aborda as mudanças nas relações de trabalho e a seção VI explora alguns impactos da maior integração produtiva asiática. Enfim, a seção VII sumariza os desafios atuais da economia japonesa, destacando o programa recentemente adotado com o intuito de recuperar a economia. A seção VIII esboça as considerações finais.

\section{As instituições e a economia política do milagre japonês}

Entre 1948 e 1973, o crescimento econômico per capita japonês foi de 8,2\% ao ano, de longe o maior entre os países desenvolvidos. A economia japonesa desenvolveu uma estrutura econômica e tecnológica avançada e tornou-se a segunda maior economia do mundo. O bom desempenho foi significativamente favorecido pelo atraso relativo do país e pelas possibilidades de convergência (catch up), mas foi também decisivamente influenciado por instituições que favoreceram altas taxas de investimento e de aumento da produtividade e o fortalecimento das empresas. O Japão desenvolveu também um sólido e dinâmico sistema de inovação (Coates 2000).

Elementos culturais desempenharam um papel importante. Estudos indicam que a ambição e a disposição dos asiáticos a dedicarem longas horas ao estudo e ao trabalho contribuíram para os bons resultados. Da mesma forma, elementos culturais que valorizam o consenso e rejeitam o conflito contribuem para a redução dos custos de transação. No entanto, entender o desempenho japonês requer compreender os elementos institucionais típicos desse modelo de capitalismo. Requer responder às seguintes questões: (i) em que sentido o Japão é diferente?; (ii) como essas diferenças influenciaram o desempenho econômico?; (iii) por que deixaram de ser positivas a partir dos anos 1990 ? $^{2}$

${ }^{2}$ Essa última questão, bastante complexa, envolve tanto elementos internacionais como institucionais e domésticos. Embora procuremos estabelecer um diálogo com os principais fatores internacionais, incluindo elementos ligados ao
Uma primeira particularidade diz respeito à organização empresarial, caracterizada pela formação de grandes conglomerados e pela ligação das empresas pela posse de ações cruzadas. Essa forma de organização teve sua origem nos grupos familiares no século XIX e, após desmontada pela ocupação norteamericana, voltou a se configurar, sob novas bases, no pós-guerra. Essa organização favoreceu o bom desempenho de duas formas: inicialmente, a relação 
sistema monetário internacional e a mudanças geopolíticas, é necessário enfatizar que a ênfase principal será dada aos fatores institucionais (ver Johnson 1998).

3 A existência de uma fonte mais paciente de capital permitiu às empresas priorizarem considerações de mais longo prazo (Guimarães 2007). próxima com os bancos do conglomerado propiciou a mobilização de capital a baixos custos e risco, estimulando o investimento ${ }^{3}$. Em segundo lugar, a proximidade entre as empresas favoreceu práticas conjuntas de cooperação técnica, desenvolvimento do produto e pesquisa e desenvolvimento. A presença de firmas de diferentes setores permitiu a acumulação de economias de escopo (Coates 2000).

Outro fator positivo diz respeito ao desenvolvimento de relações de longo prazo entre as firmas e os fornecedores. As firmas disponibilizavam assistência técnica e pessoal qualificado, garantindo que os fornecedores não seriam abandonados em tempos de dificuldades. $\mathrm{O}$ arranjo incentivava os fornecedores a investirem no aperfeiçoamento do produto, reduzindo significativamente os custos de transação. Dessa forma, mostrou-se essencial para o desenvolvimento do sistema just in time (Guimarães 2007).

Outro componente institucional diz respeito à estrutura de governança corporativa e às relações de trabalho. Em resposta à necessidade de obter apoio dos trabalhadores, desenvolveu-se um modelo de firma como uma grande comunidade. Foram concedidos mecanismos de participação aos trabalhadores e os conselhos de trabalhadores foram fortalecidos, em uma estrutura pouco afeita à influência dos acionistas (Jackson 2001). Essa concepção da firma é essencial para entender as práticas como trabalho vitalício e senioridade, que levaram a um comprometimento mútuo entre empresa e trabalhador: a firma via o trabalhador como um ativo de longo prazo, enquanto o trabalhador, mais seguro, mostrava-se propenso a investir em habilidades específicas à empresa. $\mathrm{O}$ arranjo também favoreceu a aproximação entre gerentes e trabalhadores, tornando o modelo menos hierárquico e rígido. Essa proximidade foi decisiva para o desenvolvimento do modelo de produção enxuta, que revolucionou o padrão manufatureiro mundial. Esse modelo, baseado na formação de trabalhadores polivalentes, no trabalho em equipe e em linhas de montagem flexíveis, fortaleceu o controle de qualidade, reduziu os custos de estoque e ampliou a capacidade de as empresas responderem às flutuações de demanda, conferindo grandes vantagens às firmas japonesas (Coates 2000).

Outro traço institucional diz respeito ao papel do Estado, que exerceu um grau de intervenção e uma capacidade de coordenação até então únicos na história do capitalismo. A atuação estatal, comandada pelo Ministério da Indústria e Comércio Exterior (MITI), centrou-se no fortalecimento da indústria e em sua capacidade de enfrentar a competição estrangeira. Para isso, regulou a entrada de capital estrangeiro, auxiliou as empresas em contratos de importação de tecnologia, concedeu incentivos fiscais e linhas de financiamento em condições favoráveis e usou a política de compras públicas para impulsionar as firmas locais. Ao mesmo tempo, o MITI promoveu um ambiente de competição entre os grupos empresariais e combinou os incentivos com exigências de desempenho, visando evitar a acomodação. Em certos setores, a ação era voltada a evitar a competição excessiva e impedir a acumulação de capacidade ociosa (Johnson 1982). Enfim, esforços significativos foram adotados no fortalecimento de redes envolvendo empresas, agências estatais, laboratórios e universidades, visando promover a capacidade de inovação.

Em síntese, esses fatores se combinaram em um arranjo institucional que contribuiu significativamente para o avanço econômico. O modelo foi considerado um caso singular de sucesso, admirado pelos mecanismos de coordenação e pela capacidade de atingir certos consensos. Embora essas características não estivessem disseminadas para todos os setores, compunham o núcleo central da economia e envolviam muitas das principais empresas. A esses fatores se somaram outros elementos não menos importantes, como o grande inves- 
timento em educação, as altas taxas de poupança, o contexto geopolítico e as relações desenvolvidas com os Estados Unidos (Pempel 1998).

Na década de 1970, a economia japonesa sofreu os impactos do choque do petróleo, mas demonstrou capacidade de resposta, avançando em setores como automobilística e eletrônica e conquistando nichos nos mercados norteamericano e europeu. No entanto, mudanças significativas se seguiram, incluindo as transformações no contexto internacional e o acirramento das pressões para que o Japão abrisse a sua economia (Johnson 1998). No período 19731990, apesar da desaceleração, o Japão ainda alcançou resultados comparáveis ou superiores a outros países desenvolvidos. As dificuldades vieram na década de 1990, quando a economia japonesa cresceu apenas 1,3\% ao ano, bem menos do que os $2 \%$ alcançados pela Europa e os 3,4\% dos Estados Unidos (Boltho \& Corbett 2000). A produtividade passou a crescer a taxas modestas e muitas empresas japonesas perderam espaço nos respectivos setores. Após ter alcançado os melhores índices de competitividade no final dos anos 1960, o Japão caiu significativamente e em 1997 ocupava apenas o 14 lugar (Pempel 1998).

Contextualizando a crise, a Tabela 1 apresenta uma comparação do desempenho das variáveis investimento e crescimento anual (\%) do Produto Interno Bruto (PIB) entre as economias japonesa, americana e alemã no período 1990 a 2014.

A seção seguinte busca entender os fatores responsáveis por essa mudança e compreender por que os elementos responsáveis pelo sucesso anterior deixaram de funcionar. Para isso, lida também com as causas da crise dos anos 1990 e com a incapacidade de recuperar a economia.

\section{Mudanças, crise e impasse nos anos 1990}

${ }^{4}$ Tratava-se de um arranjo diferente de proteção social, voltado a proteger setores $\mathrm{e}$ regiões deprimidos economicamente.
Entender a mudança na trajetória japonesa passa, inicialmente, por enfatizar as significativas transformações que, entre os anos de 1950 e de 1990, ocorreram em diversas esferas do modelo japonês. Como argumenta Pempel (2006), as décadas de 1950 e 1960 foram marcadas pela consolidação de um projeto hegemônico de desenvolvimento, baseado na adoção de políticas industriais agressivas voltadas à produção de campeões nacionais. O regime ancorava-se em um arranjo político conservador, capaz de acomodar setores menos dinâmicos como agricultores, pequenos comerciantes e pequenos empresários da construção civil e do setor financeiro. Essa acomodação era feita por meio de subsídios, crédito barato e proteção contra a concorrência ${ }^{4}$. O apoio a esses segmentos mostrou-se fundamental para a perpetuação do Partido Liberal Democrata (LDP) no poder.

Tabela 1 - Indicadores selecionados de comparação entre Japão, EUA e Alemanha - 1990/2014

\begin{tabular}{lcccccccccccccc}
\hline Países & & 90 & 92 & 94 & 96 & 98 & 00 & 02 & 04 & 06 & 08 & 10 & 12 & 14 \\
\hline Crescimento & Japão & 5,6 & 0,8 & 0,9 & 2,6 & $-2,0$ & 2,3 & 0,3 & 2,4 & 1,7 & $-1,0$ & 4,7 & 1,7 & $-0,1$ \\
anual do PIB & EUA & 1,9 & 3,6 & 4,0 & 3,8 & 4,5 & 4,1 & 1,8 & 3,8 & 2,7 & $-0,3$ & 2,5 & 2,3 & 2,2 \\
& Alemanha & 5,7 & 1,5 & 2,5 & 0,8 & 1,7 & 3,3 & 0,0 & 0,7 & 3,9 & 0,8 & 3,9 & 0,9 & 1,4 \\
\hline Investimento & \multirow{2}{*}{ Japão } & 32,5 & 30,6 & 28,0 & 28,6 & 26,1 & 25,1 & 22,5 & 22,5 & 22,7 & 23,0 & 19,2 & 20,8 & 22,2 \\
& EUA & 21,5 & 20,0 & 21,2 & 21,6 & 22,9 & 23,6 & 21,6 & 22,5 & 23,3 & 20,8 & 18,4 & 19,1 & 20,0 \\
& Alemanha & 23,1 & 23,5 & 22,5 & 21,4 & 21,8 & 22,3 & 18,1 & 17,6 & 18,1 & 19,2 & 17,3 & 17,3 & 16,8 \\
\hline
\end{tabular}

Fonte: Os autores, a partir dados da OECD (2015). 
${ }^{5}$ Principalmente as questões ligadas ao armistício com os Estados Unidos e à renúncia a um exército.
${ }^{6}$ Há vários exemplos em que o excesso de regulação conduziu a resultados indesejáveis, incluindo uma série de exigências burocráticas que prejudicaram
A economia japonesa era marcada pela combinação entre água e óleo: grandes empresas, que logo se tornariam internacionalmente competitivas, conviviam com grupos dependentes da ajuda do Estado. Naquele contexto, as altas taxas de crescimento facilitaram a acomodação. O regime conservador, ao mesmo tempo em que obteve êxito em despolitizar questões polêmicas ${ }^{5}$, apostou nas altas taxas de crescimento e nas possibilidades de ascensão social para se legitimar. Em síntese, havia uma combinação de políticas e instituições que produziu um vigoroso processo de crescimento econômico e de estabilidade política. Contou para isso com um sistema internacional favorável tanto à intervenção estatal como ao crescimento das exportações (Pempel 1998; 2006).

Esse regime foi abalado a partir da década de 1970, resultado tanto de transformações domésticas como internacionais. Uma dimensão crítica foi a cisão entre os interesses empresariais. As grandes empresas internacionalizadas obtiveram, com a liberalização financeira, capacidade de se autofinanciar, tornando-se menos dependentes dos empréstimos bancários e do governo. Como resposta a forte valorização do iene nos anos 1980, transferiram parte da produção para o exterior e fortaleceram os investimentos em operações financeiras.

Às mudanças domésticas se somaram as transformações ocorridas no âmbito internacional, incluindo as mudanças no regime cambial, a desregulamentação financeira e a maior mobilidade no fluxo de capitais, transformações que tornaram impossível o insulamento do modelo japonês. Nas décadas de 1950 e 1960, o câmbio foi mantido desvalorizado para promover as exportações, enquanto o acesso à moeda estrangeira foi usado como instrumento de política industrial. Essas direções tornaram-se inviáveis a partir dos anos 1970, quando pressões se intensificaram visando barrar a entrada de produtos japoneses em nichos do mercado norte-americano e europeu (Pempel 2006; Johnson 1998).

Pressões surgiram voltadas a desregulamentar o modelo japonês e facilitar a entrada tanto de mercadorias como de investimentos financeiros. Muito dependente dos EUA, o Japão não teve como resistir às imposições, o que levou a direções que comprometeram a regulação do seu modelo de capitalismo. Em face dos enormes superávits comerciais, foram intensificadas as pressões sobre o iene, que culminaram em forte valorização a partir de 1985. A volatilidade cambial que se seguiu, aliada à falta de regulamentação sobre os fluxos de capital, desempenhou papel decisivo para a crise financeira que paralisou a economia nos anos 1990 (Hamada \& Okada 2009).

Essas transformações tiveram grandes implicações políticas. Primeiro, porque as grandes empresas passaram a ter outros interesses, demandando medidas que favorecessem a desregulamentação e o maior acesso às importações, enquanto outros segmentos continuavam dependentes da proteção governamental (Pempel 2006). Segundo, porque reduziu significativamente a capacidade de a burocracia influenciar o modelo econômico, principalmente no que tange à regulação do sistema financeiro, comprometendo os mecanismos informais de regulação vigentes e introduzindo forte grau de instabilidade na economia (Gao 2001). Os burocratas, treinados como generalistas, encontraram enormes dificuldades para lidar com o contexto instável e complexo inerente à nova fase do capitalismo. Ao mesmo tempo, a capacidade de intervenção era arranhada pela emergência de vários escândalos de corrupção, que contribuíram para abalar a identificação da burocracia como uma entidade voltada à promoção do interesse nacional ${ }^{6}$.

$\mathrm{O}$ fato que mais contribuiu para o abalo no prestígio da burocracia foi a formação da bolha e a crise que se seguiu. O governo, ao adotar uma política monetária muito expansionista, contribuiu para o excesso de investimento e para a formação da bolha. A reação à crise, com o dispêndio de bilhões de ienes 
a ajuda internacional e o resgate durante um grave terremoto em Kobe (Pempel 1998).

\footnotetext{
${ }^{7}$ Os déficits

norte-americanos, no entanto, estavam muito mais relacionados a decisões políticas, ao excesso de consumo e à baixa poupança. Segundo MacKinnon e Ohno (2001), já em 1977 o iene estaria ajustado ao dólar em termos de paridade de poder de compra (PPP). Em 1985, ano do Acordo de Plaza, o iene estaria valorizado em $17 \%$.

${ }^{8}$ A cotação dólar-iene, que estava em 1 dólar $=239$ ienes em setembro de 1985, passou para 1 dólar $=158$ ienes ao final de 1986 e chegou a atingir 1 dólar $=80$ ienes em meados dos anos 1990
}

\footnotetext{
9 Também influenciada pelo aumento da taxa de poupança resultante do envelhecimento da população, dado o tímido sistema de seguridade social.
}

para socorrer bancos e empresas fortemente envolvidos em especulação, teve impactos muito negativos sobre a opinião pública. Por sua vez, em um contexto de rápidas mudanças, em que o acesso a algumas tecnologias tornava-se estratégico, o excesso de regulação comprometia o desempenho de diversos setores (Pempel 1998).

A longa e persistente crise que assolou a economia japonesa a partir dos anos 1990 é um fenômeno instigante, principalmente por ter ocorrido em um país com tal histórico de sucesso. O estopim foi a explosão da bolha formada nos mercados imobiliário e de ações. Nos anos de formação da bolha, empresas e bancos atuaram agressivamente. As empresas aproveitaram os amplos canais de acesso ao financiamento, prestando pouca atenção à lucratividade dos investimentos. Os bancos procuraram suprir a perda dos clientes maiores direcionando as operações para aplicações de maior risco. Todo o processo foi alimentado por uma política monetária muito expansiva, criticamente influenciada pelas pressões norte-americanas, que atribuíam a uma suposta desvalorização do iene a responsabilidade pelos altos superávits japoneses ${ }^{7}$.

Essas pressões conduziram ao Acordo de Plaza, em 1985, que acarretou forte valorização do iene nos anos seguintes ${ }^{8}$, contribuindo para transformar o Japão em grande detentor de ativos financeiros internacionais. Em 1987, com a Black Monday e a queda do mercado de ações em Nova York e Londres, houve forte desvalorização do dólar e grande influxo de capital para o Japão. As autoridades japonesas, assim como as de outros países, tiveram pouca opção a não ser reagir reduzindo os juros. Seguiu-se uma política monetária muito expansionista, que visava também atender aos interesses dos exportadores industriais, prejudicados pela valorização do câmbio. Essa política alimentou a expansão das operações no mercado de imóveis e de ações. Como consequência, o índice do mercado de ações Nikkei 225 dobrou entre 1987 e o fim de 1989. Quando as autoridades monetárias procuraram corrigir o excesso, aumentando os juros, provocaram a explosão da bolha (Hamada \& Okada 2009).

O fim da bolha especulativa foi marcado por forte queda do preço dos ativos. O índice de ações caiu $50 \%$ e o preço dos imóveis $25 \%$, resultando em perda de riqueza equivalente a dois anos do PIB (Boltho \& Corbett 2000). A queda no consumo e o excesso de capacidade na economia, deprimindo o investimento, foram fatores essenciais para o agravamento da crise ${ }^{9}$. Outra consequência foi a acumulação de empréstimos impagáveis e a deterioração na situação dos bancos. Em síntese, a crise japonesa seguiu inicialmente o script de outras grandes bolhas financeiras. O que foi surpreendente foi a duração da estagnação e a incapacidade de recuperação. Ao longo da década de 1990, com exceção de 1996, o crescimento do PIB foi inferior a 1\%, sendo negativo em 1998 e nulo em 1999. O período foi marcado por persistente deflação: entre 1991 e 1998, a inflação caiu para zero, tendo sido negativa entre 1999 e 2003, em 2005 e em 2006 (MacKinnon \& Ohno 2001).

Um ponto central é entender por que as políticas convencionais de estímulo à demanda não funcionaram. A política monetária foi expansiva durante o período: em 1994, a taxa de juros atingiu 2\%, tendo sido reduzida para 0,5\% em 1996 e para zero em 1999 (MacKinnon \& Ohno 2001). Apesar dos juros nominais muito baixos, a perspectiva de deflação tendia a aumentar os juros reais. Segundo Paul Krugman e outros economistas, seria necessária a adoção de políticas mais agressivas de compra de títulos e ativos visando convencer os atores de que a economia sofreria uma inflação, reduzindo assim os juros reais e estimulando os gastos. Caberia ao governo, segundo esses autores, adotar uma meta de aumento inflacionário e tomar todas as medidas necessárias para alcançar esse objetivo (Boltho \& Corbett 2000). 
${ }^{10}$ Os empréstimos podres, negligíveis em 1993, atingiram $20 \%$ do PIB em 2005. As perdas do sistema financeiro foram estimadas em mais de US\$ 1 trilhão.
${ }^{11}$ Em 1996, a economia apontava para um crescimento anualizado de 5\%, favorecida inclusive pela desvalorização do iene. Há interessante paralelo com a decisão do governo Roosevelt, em 1937. recolocando a economia em crise.
Fraga e Strachman (2013), por sua vez, argumentam que a principal razão para o não funcionamento da política monetária foi a quebra dos mecanismos de transmissão monetária, decorrente das dificuldades enfrentadas pelo setor bancário, agravadas pela crise asiática de $1997^{10}$. Em face da vulnerabilidade financeira, das incertezas, da relutância das empresas em investir e dos baixos juros, que reduziam a lucratividade, os bancos relutavam em conceder novos empréstimos. Em tal contexto, políticas voltadas simplesmente a expandir a liquidez e reduzir os juros não funcionavam; era necessário enfrentar a questão dos empréstimos podres, recuperar a situação dos bancos e aumentar a disposição para conceder empréstimos.

Também a política fiscal se mostrou incapaz de reverter a crise. Uma série de medidas de estímulo fiscal foi introduzida, com a canalização de recursos principalmente para obras públicas, estímulo a pequenas e médias empresas (PMEs), apoio aos idosos e crédito a famílias privadas de liquidez (Fraga \& Strachman 2013). Pelo lado da receita, o governo reduziu impostos que incidiam sobre o rendimento e sobre o consumo, embora de forma errática. Como resultado, houve significativo aumento do déficit fiscal, que excedeu $10 \%$ do PIB em 1999. A dívida pública teria crescido de 58,2\% do PIB em 1991 para 114\% em 2000 e 120\% em 2001 (MacKinnon \& Ohno 2001).

No entanto, diversos fatores reduziram o impacto das medidas fiscais. Em primeiro lugar, o investimento público foi menor do que inicialmente previsto, com grande parcela indo para a aquisição de terrenos. Em segundo lugar, a alta proporção de recursos voltada para auxílio aos idosos e apoio a PMEs e a relativamente baixa parcela voltada a investimentos em infraestrutura reduziu o impacto do multiplicador fiscal. Os efeitos teriam sido maiores se a política estivesse voltada para famílias de baixa renda e para investimentos públicos com alto impacto na demanda privada. Terceiro, a política fiscal foi tímida e oscilante devido a certo conservadorismo fiscal, exacerbado pelo mal estado das finanças japonesas e pelo envelhecimento da população. Isso explica a desastrosa decisão de aumentar o imposto sobre o consumo em 1997, frustrando o que despontava como promissora recuperação (Fraga \& Strachman 2013; Kang, Syed \& Tokuoka 2009; MacKinnon \& Ohno 2001) ${ }^{11}$.

Outro componente essencial da crise japonesa foi a manutenção do câmbio valorizado, impedindo que o maior crescimento das exportações engatilhasse a recuperação. $\mathrm{O}$ iene esteve valorizado em todo o período, a despeito da forte compra de dólares pelas autoridades monetárias. A principal razão é que os investidores japoneses, grandes detentores de ativos financeiros, relutavam em manter ativos em dólar, optando por preservá-los em iene, a despeito das taxas de juros no Japão estarem alguns pontos percentuais abaixo das taxas norteamericanas. Isso se explica pelas expectativas de que o iene continuaria se valorizando, resultado do histórico de pressões norte-americanas e da manutenção do superávit comercial. Nesse sentido, a decisão de manter os ativos em iene, independente da baixa taxa de juros, representa outra razão para a preferência pela liquidez, frustrando a política monetária e contribuindo para a perpetuação do quadro de deflação e estagnação (MacKinnon \& Ohno 2001).

A solução passaria por estabilizar a relação iene-dólar, convencendo os agentes de que não haveria nova valorização. Para isso, seria fundamental um approach bilateral, garantindo a ausência de novas sanções e alinhando os esforços de política monetária. O problema era a dificuldade em convencer os EUA a adotar esse approach. Em várias situações os norte-americanos relutaram em cooperar; em 1999, por exemplo, se opuseram a deixar o iene se desvalorizar (MacKinnon \& Ohno 2001).

Portanto, vários fatores contribuíram para a estagnação. Alguns desses fatores estavam ligados a variáveis internacionais e à fragilidade do Japão em 
12 Houve, nos primeiros anos, medidas para recapitalizar os bancos, mas não foram acompanhadas de ações para reestruturá-los. Em áreas que não tocavam frontalmente $\mathrm{em}$ interesses constituídos, como segurança, educação e welfare state, as reformas foram mais facilmente implementadas.

\footnotetext{
${ }^{13}$ Contou decisivamente para esse processo de reformas a capacidade de mobilizar a opinião pública, insatisfeita com a paralisia e o desperdício de recursos.
}

relação aos EUA. Outros estiveram relacionados à timidez da política fiscal e à impotência da política monetária. Um componente essencial foi a demora em implementar reformas e em enfrentar incisivamente as dificuldades do sistema financeiro.

Um sério problema foi o surgimento de "firmas zumbis", incapazes de pagar os empréstimos contraídos e dependentes de ajuda governamental. Outro foi a multiplicação dos empréstimos podres. Mesmo os bancos mais sólidos perderam capacidade de socorrer empresas consideradas viáveis. As falências se multiplicaram, ampliando a incerteza. Eram necessárias medidas fortes, incluindo a reestruturação do sistema financeiro e a definição de firmas e bancos que deveriam ser salvos, assim como daqueles que deveriam falir. O problema é que muitos dos setores em dificuldades, incluindo cooperativas agrícolas, bancos, construtoras e empreendimentos varejistas, compunham a base de suporte do LDP, dificultando uma ação mais enérgica (Pempel 2006) ${ }^{12}$.

$\mathrm{Na}$ incapacidade de reformar, uma direção foi "postergar o problema", acreditando que a recuperação viria naturalmente e que uma eventual inflação depreciaria parte das dívidas. Outra foi aumentar o repasse de recursos para alguns setores politicamente sensíveis, incluindo as áreas rurais e as obras públicas, o que, apesar do agravamento do quadro fiscal, pouco contribuiu para a recuperação da economia.

Segundo Pempel (2006), a persistência dessas dificuldades estaria ligada à relação próxima entre o LDP e alguns setores econômicos. Outro ponto crítico foi a falha das instituições políticas em oferecer um programa alternativo que angariasse apoio para enfrentar o impasse. Parte da explicação estaria no sistema eleitoral, que combinava um sistema de voto distrital com um sistema de representação proporcional. O sistema de voto distrital, em turno único, permitia que candidatos fossem eleitos com 12 a $15 \%$ dos votos, favorecendo propostas muito particularistas em detrimento das mais gerais. Além disso, a super-representação das áreas rurais contribuía para bloquear certas reformas.

Além disso, os partidos de oposição eram fracos e incapazes de mobilizar os eleitores insatisfeitos com o status quo. Em 1998, o LDP, apesar do pífio desempenho nas principais regiões metropolitanas, permaneceu no poder devido aos votos de pequenas localidades e das áreas rurais (Pempel 2006). Em 2003, o LDP foi fortemente derrotado nas eleições parlamentares por representação proporcional, mas preservou o poder devido ao voto distrital. As redes de patronagem mostraram-se essenciais.

Não obstante as resistências, um programa de reformas foi amadurecendo e se solidificando ao final da década de $1990^{13}$. A partir de 1998 , foi criada uma agenda mais firme e propositiva, mudando o sistema regulatório, injetando recursos no sistema bancário e impondo direções aos bancos. Tal ajuste incluiu a atuação do Banco Central do Japão como credor de última instância e a injeção de trilhões de ienes para a recuperação das firmas viáveis, a reestruturação das inviáveis, o fortalecimento do capital de bancos solventes, o refinanciamento de empréstimos que estavam vencendo e a proteção aos depósitos de bancos falidos. Parte importante da solução foi condicionar a concessão do dinheiro público à melhoria do balanço dos bancos e à adoção dos requisitos do Acordo de Basileia, incluindo a nomeação de diretores externos e de uma comissão independente de auditoria (Kang, Syed \& Tokuoka 2009; Fraga \& Strachman 2013).

Em síntese, a efetividade das políticas monetária e fiscal demandava uma atuação mais incisiva capaz de equacionar as dificuldades do sistema financeiro. Nessa direção, a melhoria da saúde do sistema financeiro, junto com a 
maior capacidade em desvalorizar o iene, permitiu melhores resultados econômicos a partir de 2004.

\section{Mudanças na organização empresarial e no sistema financeiro}

No modelo japonês consolidado no pós-guerra, a organização empresarial (OE) e o sistema financeiro (SF) reforçavam os laços de compromisso entre os diversos stakeholders. A OE, baseada nos grandes grupos empresariais (keiretsus), resultou em alto nível de cooperação e coordenação. A estrutura de propriedade baseada nas ações cruzadas e a dependência do crédito bancário resultaram em um capital paciente e de longo prazo, vital para a preservação de relações de trabalho baseadas no emprego vitalício e na senioridade (Coates 2000). O SF era dominado pelos bancos e as empresas pouco dependiam do mercado de capitais.

Esse arranjo, não obstante, tinha também as suas dificuldades. A divulgação das informações financeiras era pouco transparente, a auditoria era realizada internamente e a contabilidade era feita por valores históricos, em vez do mais usual valor de mercado. Além disso, a relação próxima com os bancos permitia enorme mobilização de capital, que poderia conduzir, em uma conjuntura desfavorável, a investimentos imprudentes. Havia, no sistema financeiro, um mecanismo informal de regulação, que foi fortemente abalado pelas mudanças no capitalismo internacional e pelas inovações financeiras (Gao 2011).

Após a crise dos anos 1990 foram discutidas as direções que deveriam pautar o ajuste do modelo. Levantou-se, por um lado, que a economia precisaria de instituições mais apropriadas para se integrar em uma economia internacionalizada. Alegou-se, por outro, que as instituições passadas se mostrariam parte fundamental do sucesso alcançado e, uma vez contornadas as dificuldades imediatas, poderiam contribuir para o bom desempenho. O objetivo desta seção é resenhar as mudanças que vêm ocorrendo na OE e no SF, enfatizando o que vem se modificando e o que tem sido preservado.

IV.1. Sistema financeiro

O Japão vem gradualmente desregulando sua economia desde meados dos anos 1980, mas o processo acelerou-se com a crise da década seguinte. Em 1996, uma grande reforma do setor financeiro foi proposta. Tentando emular o sucesso da desregulação britânica, o "Big Bang" de Tóquio impôs uma série de mudanças, dentre as quais a permissão de bancos e corretoras negociarem derivativos, a venda de opções de ações nas bolsas de Tóquio e Osaka, o fim da reserva de mercado entre bancos, corretoras de valores e seguradoras e a liberdade para as empresas negociarem financiamentos no exterior (Craig 1998).

Para dar sustentação legal, foi criada uma agência exclusiva para regulação dos serviços financeiros, a Financial Services Agency (FSA), e conferida autonomia legal ao Banco Central do Japão (Aronson 2011; Pempel 2006). Visando facilitar o processo de reestruturação das empresas e remover as barreiras para Fusões e Aquisições (F\&A), em 1997 foi revogada a lei que proibia a formação de holding companies. No caso do sistema financeiro, tal medida foi crucial para a formação dos "megabancos", como o Bank of Tokyo-Mitsubishi, Mitsui-Sumitomo e Mizho (Vogel 2006, p.133). Outra mudança diz respeito ao enfraquecimento dos laços de ações cruzadas envolvendo os bancos, que reduziram significativamente a participação no board de direção das empresas. 
Os bancos foram criticamente afetados pela crise econômica. Devido aos empréstimos de baixa rentabilidade e à aquisição de bancos insolventes, as instituições japonesas não conseguiram fazer a transição satisfatória para o modelo de banco múltiplo, como ocorrido na Alemanha. Com a perda das firmas blue chips (empresas da $1^{a}$ seção da bolsa de Tóquio) para o mercado de capitais, os grandes bancos foram forçados a se aproximar das pequenas e médias empresas, tornando os empréstimos mais arriscados. A nova situação trouxe dificuldades para o sistema bancário em geral, provocando forte redução no número de cooperativas de crédito (Uchida, Udell \& Watanabe 2013).

Ainda assim, o sistema financeiro continua muito baseado nos bancos. Muitas empresas procuraram preservar a relação de longo prazo com os antigos bancos do conglomerado (main banks), optando pela negociação. Passaram a demandar menores taxas e melhores serviços, pressionando os bancos a melhorarem a oferta de securities. A relação com os bancos mostrou-se particularmente importante durante a crise, uma vez que rolavam empréstimos cobrando margens muito baixas. Segundo Vogel (2006, p.127), a proporção de firmas cuja relação com o banco se manteve estável por mais de cinco anos cresceu de 65\% em 1990 para 82\% em 1997.

Em face das inovações financeiras, os bancos vêm tentando preservar a lealdade dos clientes oferecendo serviços como acesso à informação, contratos internacionais, consultoria e negociações entre clientes para alianças e fusões. Vogel (2006) mostra que as grandes empresas ainda têm fortes incentivos para manter relações com seus bancos e que a decisão de financiamento não se dá exclusivamente por cálculos marginais de retorno. Entre os incentivos, inclui-se o interesse no fornecimento de crédito para as pequenas empresas afiliadas e para fornecedores. As PMEs mostram-se altamente dependentes do crédito bancário.

Em síntese, mudanças significativas ocorreram no sistema financeiro. $\mathrm{O}$ grau de autonomia e liberdade para instituições financeiras e investidores, incluindo os estrangeiros, teve considerável avanço e o SF japonês reduziu a distância que o separa dos países ocidentais. Os bancos se reorganizaram, reduzindo o excesso de capacidade por meio de fusões e queda de participação nas empresas. Como consequência, o sistema financeiro vem perdendo a característica segmentada existente outrora e os bancos passam a conciliar as funções tradicionais com operações mais típicas de bancos de investimento. Entretanto, bancos e empresas continuam desenvolvendo relações próximas e de longo prazo. Esse é um ponto muito sensível, uma vez que a eventual perda de uma fonte mais paciente de capital, acompanhada de maior ênfase nas considerações de curto prazo, tenderia a inviabilizar outros pilares do modelo japonês.

\section{IV.2. Organização empresarial e governança corporativa}

A combinação entre mudanças e conservação é bem ilustrada pelas reformas verificadas no padrão de organização empresarial $(\mathrm{OE})$ e governança corporativa (GC). Essa é uma das áreas em que as tensões envolvendo os interesses dos stakeholders, as razões do sucesso anterior e as dificuldades do presente muito se manifestam, explicando por que as reformas vêm sendo ambivalentes.

Algumas mudanças significativas ocorreram em áreas que afetaram tanto a governança corporativa como o sistema financeiro, como o aumento da participação estrangeira. Em 1990, os investidores estrangeiros detinham 4\% das ações listadas na Bolsa de Tóquio, percentual que subiu para 18,3\% em 2002. Na visão de Jackson e Moerke (2005), o crescimento dos investidores estrangeiros pôs pressão sobre os padrões de governança corporativa, já que os novos 
${ }^{14}$ O IFRS é padrão em toda União Europeia e o Japão tinha como previsão adotá-lo em 2015 ou 2016.

${ }^{15}$ Nos EUA, os fundos de pensão e as companhias de investimento controlavam $60 \%$ das empresas.

${ }^{16}$ Segundo Vogel (2006), em 2004, 630 das 2.108 companhias listadas tinham diretores externos, mas $29,8 \%$ eram originários de parceiros de negócios e $17,7 \%$ dos bancos do grupo. acionistas estão preocupados com a valorização das ações e dão pouca atenção às relações de longo prazo. Isso vem sendo acompanhado pela maior participação dos fundos de pensão nas assembleias de acionistas.

Outra mudança essencial se deu nas normas de contabilidade. O Japão, como destacado, utilizava princípios contábeis baseados em valores históricos, que permitia amortecer os resultados e/ou camuflá-los via subsídios cruzados em operações entre subsidiárias do grupo. As novas normas têm como regra o registro dos valores por preço de mercado, o que transmite maior transparência aos investidores. As leis Companies Act, de 2005, e Financial Instruments and Exchange Act, de 2006, ampliaram a divulgação de informações de empresas de capital aberto (Aronson 2011). E, desde março de 2010, foi liberado o uso do IFRS (International Financial Reporting Standarts) para algumas empresas ${ }^{14}$. Como consequência, as firmas têm se mostrado mais preocupadas com a lucratividade e mais orientadas para retornos financeiros, enquanto o foco vem se concentrando no negócio principal da companhia.

Percebe-se também redução na proporção de ações cruzadas, mas esta continua alta. O Japão continua a ter uma estrutura de propriedade das empresas bastante estável, muito similar à alemã e muito distante da norte-americana. A participação de investidores estáveis - compostos por firmas não financeiras, bancos e companhias de seguro - na propriedade das empresas teria decrescido de 66\% em 1990 para 47\% em 2004. Por sua vez, a participação de fundos de pensão cresceu de $1 \%$ para $4 \%$ e das firmas estrangeiras de $4,7 \%$ para $23,7 \%$ $\left(\right.$ Vogel 2006) ${ }^{15}$.

A combinação entre mudanças e conservação também acompanhou a introdução de compensação por stock options (opção por ações) e de diretores externos. As stock options foram introduzidas de forma cautelosa, de modo a evitar que considerações de curto prazo ganhassem importância excessiva. Diretores externos foram introduzidos no board das empresas, mas eram em geral ex-empregados ou acionistas de outra companhia do grupo, de forma que tendiam a representar os stakeholders ${ }^{16}$. A maior parte dos acionistas continuava passiva e os gerentes possuíam grande autonomia para conduzir a companhia. Além disso, $60 \%$ dos diretores das grandes corporações indicavam a presença de proteção contra aquisições, com evidências de proteção inclusive no caso de aquisições amigáveis (Vogel 2006).

O Japão tem também introduzido práticas como o componente de desempenho nos bônus e no pagamento dos trabalhadores, mas de forma cautelosa. $\mathrm{O}$ pagamento por desempenho tem sido adotado muito mais para trabalhadores de colarinho branco do que para os blue collars, uma vez que o trabalho em equipe continua essencial na linha de produção e premiar o desempenho individual pode ser nem desejável e nem prático.

Percebem-se, assim, mudanças em direção a um modelo mais favorável aos acionistas, que levaram as firmas japonesas a vender ativos e abrir mão das subsidiarias menos lucrativas. Firmas mudaram parte da produção para o exterior, subcontrataram e abandonaram linhas de produtos visando aumentar a lucratividade. A desregulamentação do mercado de capitais ampliou o risco de aquisições hostis, de forma que os gestores se tornaram mais sensíveis a defender o preço das ações. Ao mesmo tempo, a mudança de legislação permitiu o rearranjo corporativo que vem racionalizando a estrutura do tradicional keiretsu. A formação de holding companies traz mais autonomia para as empresas, além de reduções do custo trabalhista. Essas mudanças, no entanto, vêm sendo conciliadas com características típicas dos keiretsus, incluindo a relação de longo prazo com bancos e fornecedores, a autonomia dos gerentes, o papel dos stakeholders e a influência relativamente limitada dos acionistas. 
Vogel (2006) dá exemplos de como o contexto institucional continua a influenciar o comportamento de diversas empresas. No caso da Toyota, houve redução do número de trabalhadores (de 73 mil em 1992 para 67 mil em 2002) e grande incorporação de trabalhadores não regulares (número que aproximou de dez mil em 2004). O pagamento por desempenho foi introduzido para trabalhadores "colarinho branco". Os gerentes, no entanto, insistiram em manter relações próximas com os fornecedores estratégicos. Segundo diretores do grupo, os diretores externos não eram necessários, até porque não entendiam as especificidades do negócio. Os gerentes continuavam autônomos e os acionistas tinham pouca influência (Vogel 2006, p.167). No caso da Nissan, a contratação de um CEO estrangeiro, não comprometido com laços culturais japoneses, apontava para mudanças mais profundas. No entanto, o brasileiro Carlos Ghosn logo percebeu que precisava trabalhar com os sindicatos e que a reestruturação precisava ser negociada. A direção foi transferir trabalhadores excedentes para as subsidiárias do grupo e cautela foi também demonstrada em relação aos fornecedores, considerando-se que a opção por adquirir os componentes mais baratos no mercado implicaria prejuízo para a capacidade de inovar e desenvolver tecnologia.

A NEC ilustra bem o exemplo de firmas que optaram por desmontar parte das redes de produção e obter os componentes no mercado internacional. No entanto, a empresa também preservou laços de cooperação com os fornecedores considerados estratégicos. Demissões eram evitadas pela transferência de trabalhadores para as subsidiárias, enquanto a empresa mantinha mecanismos para dificultar fusões e aquisições hostis (Vogel 2006). Um quarto exemplo, a Sony, usa stock options, distribui bônus atrelados aos preços das ações e apresenta diferenças salariais altas para os padrões japoneses. Por depender do mercado de capitais, precisa de diretores externos. No entanto, a empresa, apesar de internacionalizada, age diferentemente quando atua no Japão, congelando contratações e procurando distribuir trabalhadores entre subsidiárias, quando no exterior simplesmente demite. Acionistas gostariam de mudanças mais profundas, mas o CEO responde que as normas e instituições japonesas demandam outro comportamento (Vogel 2006).

Vogel (2006) dá também exemplos de empresas no setor de serviços pouco marcadas pelos tradicionais vínculos típicos do keiretsu. O banco Shinsei, por exemplo, apostou na possibilidade de entrar em nichos mais lucrativos, procurando reestruturar firmas. No entanto, sofreu muitas críticas por não ter socorrido uma loja de departamento e tê-la deixado falir. A agência reguladora FSA disse que o banco havia recebido fundos públicos e tinha obrigação de desempenhar um papel público. Outras firmas passaram a evitar negócios com o Shinsei por acreditarem que não tratava bem os trabalhadores. Um último exemplo é a Softbank, que entrou agressivamente no mercado, baixou significativamente as taxas cobradas por serviços de internet e obteve grande número de clientes. Em 2004, no entanto, teve de reconsiderar a estratégia, uma vez que os trabalhadores passaram a vazar informações sobre serviços de clientes de banda larga. A firma logo compreendeu que era necessário ter trabalhadores mais leais, passando a adotar uma estratégia voltada a ampliar o numero de trabalhadores estáveis de 20\% para 60\% (Vogel 2006).

Em síntese, os exemplos mostram como o contexto institucional importa e tende a afetar as chances de sucesso. Firmas que procuraram introduzir agressivamente aspectos da cultura americana tiveram de recuar, uma vez que passaram a sofrer danos em termos de reputação, o que prejudicou o acesso ao financiamento e a possibilidade de fechar novos contratos.

Em uma análise mais recente, Miyajima (2012) procura, a partir das cate- 
mede as características de finanças corporativas e a estrutura de propriedade. A governança interna enfatiza o grau de separação entre proprietários e gestores, enquanto a arquitetura organizacional diz respeito às características do sistema de emprego e ao grau de descentralização dentro da organização.
${ }^{18}$ Por possuírem tecnologia de ponta, tornaram-se alvo dos investidores estrangeiros. Não obstante, apenas 27 das 327 firmas tradicionais japonesas possuíam, até 2007 , participação estrangeira superior a $15 \%$. qualificar em que medida as empresas estão se reestruturando e em que grau vêm preservando as relações tradicionais. Devido ao grau de heterogeneidade, as empresas foram classificadas em três grandes grupos. As firmas tipo I são grandes empresas que possuem muitos anos de mercado e altas taxas de exportação e de investimento em P\&D. Representam 23\% das firmas da amostra e $67 \%$ das vagas de trabalho. São dependentes do mercado de capitais para se financiar e possuem estruturas de controle e gestão mais propícias para os acionistas, com grande participação de estrangeiros no controle acionário, em média 21,9\% das ações em 2007. Essas firmas vêm reformando seus quadros de diretores e conselhos internos e também são mais transparentes na divulgação de informações. Gradualmente, vêm introduzindo sistemas de remuneração variáveis: para diretores e gerentes, oferecem pagamentos com opções de ações e, para os demais, estão adotando o sistema de pagamento baseado no desempenho. Porém, mantém o padrão de relação de emprego de longo prazo e possuem altas taxas de sindicalização dos seus funcionários. Há a manutenção de várias práticas das relações trabalhistas tradicionais.

As empresas tipo II são, em sua maioria, empresas dos setores de tecnologia da informação e de serviços. Representam $21 \%$ das empresas pesquisadas e $10 \%$ dos postos de trabalho. Possuem elevada participação de acionistas controladores e acionistas individuais e são normalmente lideradas por seus fundadores. Apesar de estarem no mercado de capitais, são muito dependentes dos bancos para se financiarem e são bem fechadas na divulgação de informações. Apresentam, em média, apenas $10 \%$ de suas dívidas lastreadas no mercado financeiro e o avanço dos investidores estrangeiros foi, entre 2002 e 2007, de apenas $2,3 \%$. Apresentam, no entanto, relações trabalhistas bem diferentes do modelo japonês tradicional. As mesmas são centradas em contratos formais e o sistema de pagamento é baseado no desempenho.

As tradicionais firmas japonesas, ou tipo III, são as que mantêm a governança corporativa com o maior grau de semelhança ao típico modelo japonês. As firmas são normalmente encontradas nos setores de construção civil, química, maquinário elétrico e máquinas de transporte. Essas firmas, que representam mais da metade da lista de empresas e $24 \%$ do total de empregos, ainda possuem relações financeiras de longo prazo com os bancos e continuam a ter baixa dependência do mercado de capitais. Além disso, não se esforçam para reformular a governança interna e o sistema de emprego, são relutantes em apontar gestores/conselheiros externos e divulgam poucas informações ${ }^{18}$.

O que se nota, tanto na análise de Vogel (2006) como na de Miyajima (2012), é o hibridismo e a falta de certeza sobre a direção das mudanças. Vogel (2006) enfatiza que as reformas foram substanciais, contrariando a ideia de esclerose e de lentidão a responder, mas foram influenciadas pelo contexto institucional doméstico. Uma hipótese testada pelo autor é que as reformas seriam mais prováveis em setores mais dinâmicos e mais expostos à competição e menos prováveis em setores mais protegidos. $\mathrm{O}$ autor, no entanto, encontra que essa hipótese não necessariamente vigora, com casos de maior conservação em nichos da indústria e maiores mudanças em certos nichos do comércio varejista. Isso se explica pelo maior interesse de setores da indústria em manter as relações de longo prazo com trabalhadores, bancos e fornecedores, dados os impactos sobre a capacidade competitiva.

As mudanças vêm sendo incrementais, mas ao afetarem o comportamento dos agentes podem acarretar novas transformações e solapar as características da governança corporativa tipicamente japonesa. Acredita-se também que a maior velocidade das mudanças no sistema financeiro possa trazer novas mudanças no sistema de organização empresarial. O ponto em questão é a interdependência entre as instituições e o papel imprescindível desempenhado 
por fontes mais pacientes de capital. Outro ponto central diz respeito ao interesse e à capacidade dos setores empresariais em continuar preservando as relações de longo prazo.

\section{Mudanças nas relações de trabalho}

O sistema de relações de trabalho que apoiou a expansão japonesa no pós-guerra articulava amplo acordo sobre moderação e flexibilidade salariais, segurança no emprego e cooperação entre operário e gerência. Para isso, garantia a participação dos operários no processo de administração e também nos resultados financeiros da empresa. Com o intuito de obter maior compromisso do trabalhador, foram estabelecidas, na década de 1950, condições efetivas para o sistema de estabilidade no emprego. Vale destacar que essa cooperação entre operários e gerência incentivava a qualificação de recursos humanos. As empresas tinham (e têm) elevadas responsabilidades pela formação desses recursos, sendo comum o operário realizar grande rotatividade entre múltiplas áreas da empresa (Vogel 2006). Esse sistema, no entanto, não atingia todos os setores, sendo restrito aos grandes grupos industriais e abarcando majoritariamente os trabalhadores do sexo masculino.

Nas décadas de 1950 a 1980, o bom desempenho da economia teve impactos muito favoráveis sobre o mercado de trabalho, permitindo a consolidação das relações de trabalho. As dificuldades iniciaram-se em meados dos anos 1980 e se agravaram com a crise nos anos 1990. Outro fator relevante foi a internacionalização da economia, com a transferência de etapas da produção manufatureira para outros países. No início dos anos 2000, as empresas japonesas empregavam 2,9 milhões de trabalhadores no exterior, valor que correspondia a um quarto do emprego manufatureiro gerado por essas empresas no Japão (Suzuki 2010).

A internacionalização e a maior exposição à competição global passaram a exigir ajustes rápidos para enfrentar a variação no ciclo dos negócios, pressionando por modificações em aspectos da organização da empresa japonesa. Houve impacto na direção de facilitar os processos de fusões e reorganização societária, mudança com implicações sobre a ação dos sindicatos que, organizados em base empresarial, precisaram modificar a estratégia e realizar a negociação coletiva com a holding (Suzuki 2010).

Assim, a internacionalização e a crise agiram como catalizadores para mudanças nas relações de trabalho. Um marco foi a legalização parcial do trabalho não regular, em 1986. Em um primeiro momento, essa medida teve pouca influência, pois as empresas optaram por métodos tradicionais para reduzir os custos, incluindo moderação salarial. No entanto, o aprofundamento das dificuldades levou à intensificação do uso do trabalhador não regular. Ao final dos anos 1990, nova mudança na regulação lançou as bases para a maior liberalização do trabalho temporário. Foi aprovada uma lei que deu aos empregadores maior flexibilidade para definir o contrato de trabalho, incluindo as cláusulas relativas à remuneração e à demissão dos trabalhadores (Suzuki 2010).

Como consequência, houve grande expansão dos trabalhadores não regulares. O número de trabalhadores não regulares do sexo masculino passou de 1,94 para 5,27 milhões entre 1987 e 2006, enquanto o emprego não regular feminino passou de 5,17 para 11,34 milhões. O trabalho não regular deixou de ser uma característica eminentemente feminina, com a participação masculina passando de $20 \%$ em 1997 para $38 \%$ em 2007. Em meados dos anos 2000, os trabalhadores não regulares representavam um terço do total da força de trabalho ocupada no Japão (Suzuki 2010; Sako \& Kotosaka 2010). 
Pesquisa realizada na primeira metade dos anos 2000 revelou que, entre 1.602 empresas pesquisadas, 1.460 contrataram algum tipo de trabalhador não regular. Entre os motivos, o mais comum, indicado por $76,6 \%$ das empresas, foi a redução dos custos trabalhistas, enquanto $46,9 \%$ delas indicaram o motivo de ajustar o emprego às flutuações do ciclo de negócios e às variações na demanda (Suzuki 2010).

O resultado foi a enorme hibridização e dualização do mercado de trabalho: de um lado, um grupo de trabalhadores com elevado grau de proteção; de outro, um número crescente de trabalhadores não regulares com baixíssimo grau de direitos. A direção vem sendo preservar o emprego permanente para um segmento de trabalhadores, restringindo-o a uma parcela cada vez menor da força de trabalho. Em outras palavras, o trabalho temporário, ao reduzir custos e conferir maior flexibilidade, contribui para que as empresas possam arcar com práticas como o emprego vitalício (Coe, Johns \& Ward 2011). Por sua vez, a decisão de privilegiar os incumbentes e manter a estabilidade no emprego implica maiores dificuldades para a entrada de jovens, contribuindo para o elevado desemprego nesse segmento e para o envelhecimento da força de trabalho.

O resultado foi a geração de um sistema de relações de trabalho dos mais duais entre os países da Organização para a Cooperação e Desenvolvimento Econômico (OECD). A proporção de trabalhadores temporários, classificados como aqueles que trabalham menos de 30 horas por semana, cresceu de 19,2\% em 1990 para 25,5\% em 2004 (Vogel 2006). São grandes as implicações sociais, uma vez que o emprego não regular paga menos e tem baixa cobertura em termos de previdência e outros mecanismos de proteção, o que se torna particularmente grave em tempos de crise. A separação entre empregados regulares e não regulares é ainda mais grave em decorrência da inexistência de ponte entre ambos, uma vez que aqueles que obtêm um emprego atípico/não regular dificilmente terão acesso a um emprego regular. Isso é particularmente verdadeiro para o caso dos jovens de emprego temporário, referidos como freeters, e das mulheres com filhos novos, independente dos elevados níveis de escolaridade (Coe, Johns \& Ward 2011).

Apesar das mudanças, a adoção de práticas de liberalização não implica que o sistema de emprego japonês esteja convergindo para um sistema próximo ao americano (Jacoby 2007). A evidência sugere que tal convergência é limitada e geograficamente desigual. O melhor é caracterizar o sistema japonês como híbrido, marcado pela combinação entre medidas de flexibilização e a manutenção das práticas tradicionais. Outras práticas vêm surgindo, incluindo o aumento das contratações de profissionais em meio de carreira e do pagamento por desempenho, medidas que enfraquecem as práticas de promoção interna. Assim, o emprego no Japão vem se tornando mais diversificado, o que tende por sua vez a enfraquecer os sindicatos. Apesar da disseminação de novas modalidades, as relações de emprego permanente e senioridade continuam importantes, uma vez que tendem a estimular o investimento em certas habilidades críticas para o sucesso competitivo (Vogel 2006).

Em síntese, as transformações podem ser descritas como um processo de mudança, adaptação e conservação. As mudanças na legislação deram maior flexibilidade para as empresas utilizarem trabalho temporário e para a alocação de trabalhadores entre as empresas. Mas não implicaram necessariamente facilidade de demitir, até porque muitas delas preservaram o sistema de proteção ao emprego e a participação dos trabalhadores nas decisões como forma de reter os melhores quadros. As empresas vêm se reestruturando, mas procurando evitar demissões diretas. Uma direção vem sendo promover mudanças de forma acordada com os trabalhadores, procurando ampliar a flexibilidade, reduzir 
19 As diferenças salariais entre gerentes e trabalhadores do chão da fábrica teriam caído, entre 1990 e 2004, de 3,29 para 3,12 para homens e de 3,33 para 3,05 para mulheres. custos, ampliar a produtividade e, em caso necessário, restringir os salários. Outra direção foi a alocação dos trabalhadores para as plantas e/ou subsidiárias com maiores necessidades. Assim, o emprego vitalício tem sido transferido da empresa para o grupo, sendo práticas comuns a promoção de aposentadoria precoce e a criação de afiliadas para absorver o excesso de trabalhadores (Vogel 2006).

Na mesma direção, práticas como o componente de desempenho por bônus vêm sendo introduzidas de forma cautelosa. O pagamento por desempenho, como destacado, tem sido mais comum para os trabalhadores "colarinho branco", dada a importância de preservar o espírito de equipe no chão da fábrica. No geral, o Japão tem preservado baixas diferenças salariais, em grande contraste com os Estados Unidos ${ }^{19}$. A conservação das práticas trabalhistas reflete-se também no tempo médio de emprego dos trabalhadores regulares, que teria passado de 10,9 anos em 1990 para 12,1 anos em 2004 (Vogel 2006).

Conclusões mais gerais sobre o impacto das relações de trabalho sobre a produtividade são difíceis, inclusive devido às diferenças entre setores e empresas e à combinação de diferentes modalidades de emprego. No entanto, a evolução do indicador da produtividade geral da economia japonesa nas últimas duas décadas não autoriza conclusões pessimistas. Nos anos 1990, o desempenho japonês foi próximo ao de outros países do G7, tendo sido superado apenas por Reino Unido e Alemanha. No período de 2000 a 2012, o Japão apresentou expansão da produtividade superior às economias da França, Alemanha, Itália e Reino Unido, sendo superado apenas pelos Estados Unidos (OECD 2013). Em relação ao salário real, este cresceu, entre 1997 e 2006, menos no Japão do que na maior parte dos países da OECD, de forma que o custo unitário do trabalho caiu mais do que na maior parte dos países em comparação (OECD 2013). Esses indicadores tendem a contribuir para a maior competitividade da economia japonesa, mas devem ser observados em conjunto com a evolução da taxa de câmbio e com a capacidade de inovação.

\section{A integração produtiva asiática e os impactos sobre o modelo japonês}

O aprofundamento da integração econômica asiática começou a se dar nos anos 1980, motivado pelo afluxo de investimentos japoneses em resposta à valorização do iene. Naquele momento, as economias asiáticas beneficiaram-se do acesso ao capital, tecnologia e modelo de negócios, especializando-se em elos de produção que não mais interessavam às firmas japonesas. $\mathrm{O}$ arranjo ficou conhecido como modelo dos gansos voadores.

A integração inicial foi eminentemente econômica, mas passou, com o tempo, a estimular movimentos de cooperação no campo formal, uma vez que os interesses em jogo passaram a demandar regras que transcendessem as legislações nacionais. Além disso, a maior interdependência financeira apontava para a necessidade de mecanismos de coordenação e proteção. Um marco foi a crise asiática de 1997: as enormes dificuldades, seguidas por imposições do Fundo Monetário Internacional motivadas essencialmente por interesses norte-americanos, sinalizaram para a urgência de mecanismos regionais de cooperação. Após tentativas frustradas, a iniciativa de Chiang Mai, em 2000, viabilizou a criação de uma rede de proteção financeira voltada a canalizar recursos para países em dificuldades (Breslin 2010).

Além disso, houve o paulatino fortalecimento de fóruns voltados a tratar temas de interesse mútuo, incluindo crime organizado, combate ao terrorismo e prevenção a doenças infecciosas. Houve o amadurecimento do conceito de região em termos cognitivos, significando que algumas questões só avançariam se tratadas conjuntamente. No entanto, a multiplicação de instâncias, incluindo 
${ }^{20}$ Em contraste com as firmas europeias e norte-americanas que, ao concentrarem a produção na China, obtêm economias de escala e terceirizam etapas mais elaboradas.

${ }^{21}$ A participação japonesa nas exportações mundiais de produtos eletrônicos reduziu de $10,2 \%$ em 1986 para $7,6 \%$ em 2000 (Enrst 2006, p.162). algumas abertas à participação de Estados Unidos, Austrália e Índia, tende a trazer dificuldades e incerteza, principalmente em relação a qual fórum e com quem se deve mover em primeira instância (Corning 2011).

Paralelamente, ocorreu nas últimas décadas o enorme aprofundamento da integração econômica asiática, motivado principalmente pela disseminação de novas formas de organização da produção e pela ascensão da China. Houve significativa reorganização dos fluxos comerciais, com firmas japonesas, taiwanesas e coreanas, entre outras, exportando componentes para a China, onde o produto passa a ser montado e exportado. Como consequência, as exportações intrabloco asiático cresceram significativamente, passando a responder por grande parte das exportações totais.

Deu-se um processo de significativa redefinição das cadeias produtivas mundiais, facilitada pelos avanços nas tecnologias de telecomunicações e por mudanças nos novos paradigmas produtivos. Os controles numéricos reduziram as habilidades necessárias em muitas etapas. No setor eletrônico, a modularização da arquitetura de produção, com a divisão do produto em subsistemas a partir de um desenho comum, reduziu o grau de coordenação necessária e viabilizou a montagem de etapas de baixo valor agregado em países emergentes (Ernst 2006). Essas tendências favoreceram a concentração da montagem de componentes em um único destino, transformando a Ásia em uma rede de economias que funciona como a fábrica do mundo. Empresas americanas e europeias passaram crescentemente a terceirizar etapas da produção para a China e outros países, visando reduzir os custos e ampliar a produtividade.

Essas mudanças tiveram fortes implicações para as firmas japonesas. A relação construída nos anos 1980, centrada em explorar mão de obra barata e dar aos países vizinhos nichos menos elaborados, deixou de ser viável. Alguns países avançaram e passaram a competir com os japoneses em vários nichos. Além disso, as firmas japonesas, por terem chegado mais cedo ao mercado chinês, haviam sofrido fortes exigências em termos de formação de joint ventures e proibição de atuação em alguns elos da cadeia produtiva. As empresas optaram então por estratégias defensivas, preocupadas com a falta de garantias legais e com a pirataria. Uma tendência foi a diversificação dos investimentos para vários países ${ }^{20}$.

O novo contexto passou a exigir estratégias diferentes, mas as empresas japonesas demoraram para se adaptar, acarretando erosão de liderança em setores em que as vantagens eram significativas, incluindo semicondutores e nichos da eletrônica de consumo (Ernst 2006) ${ }^{21}$. As dificuldades estavam em parte relacionadas ao modelo japonês de organização empresarial, o mesmo que tanto havia contribuído para o dinamismo anterior. O comprometimento com o emprego vitalício levava as empresas a realizar as etapas mais elaboradas no Japão, terceirizando etapas mais padronizadas. Ao fazer isso, deixavam de aproveitar a mão de obra barata e qualificada presente na China. De forma similar, a relação de longo prazo construída com os fornecedores explica a estratégia menos agressiva de terceirização. Algo similar se aplica à rotina de gerenciamento e controle aplicado às subsidiárias: o controle é feito nas matrizes e pouca autonomia é conferida às subsidiárias, o que coloca dificuldades para moldar a estratégia a partir das especificidades locais e para diferenciar o produto.

Um dos problemas mais críticos é a baixa capacidade de recrutar os recursos humanos locais. As subsidiárias japonesas insistiram por muito tempo em importar profissionais especializados e gerentes do Japão. Ao fazerem isso, barravam as chances de ascensão dos profissionais locais e falhavam em atrair os trabalhadores mais talentosos. Eram claros os efeitos negativos em termos de comunicação entre gerentes e trabalhadores e de moral do staff. A imposição de limites até onde os trabalhadores locais podiam avançar desmotivava a equipe, 
que se esforçava por fazer o mínimo. Quanto mais qualificados os trabalhadores, mais insatisfeitos com a política da empresa. Como resultado, as firmas japonesas falhavam em atrair gerentes e engenheiros qualificados (Ernst 2006).

Em face dessas dificuldades, detectadas desde o final dos anos 1990, as empresas japonesas vêm buscando se adaptar, o que passa por uma estratégia mais flexível e descentralizada de recursos humanos e pela terceirização de investimentos em $P \& D$ para as subsidiárias, delegando responsabilidade em termos de desenho e desenvolvimento do produto. Outra direção passou a ser a concentração dos investimentos na China, visando beneficiar os ganhos em termos de logística e recursos humanos. As firmas japonesas passaram também a buscar parecerias com as empresas chinesas, visando beneficiar das redes de distribuição local e aumentar a produção em solo chinês (Ernst 2006).

A grande consequência desse novo cenário é colocar pressão adicional sobre o modelo japonês, dificultando o insulamento e exigindo maior flexibilidade. O fortalecimento da China e de outros países como lócus de produção aumenta a necessidade de se integrar produtivamente para reduzir custos. A economia japonesa é relativamente fechada e $85 \%$ do valor adicionado das exportações é realizado no Japão (Ueno \& Yamano 2014). Isso aponta, segundo Ueno e Yamano (2014), para a necessidade de as empresas japonesas se integrarem nas redes globais de produção, marketing e inovação, contratando trabalhadores estrangeiros e adotando estratégias internacionalizadas. Em síntese, a capacidade de competição em certos setores exige estratégias de flexibilização. O grande desafio é conciliá-las com a preservação de algumas formas de regulação mais coordenada que, se bem dosadas, têm potencial para contribuir.

\section{Abenomics, estímulo macroeconômico e os desafios estruturais}

Em face da estagnação econômica, tentativas de ajuste vêm sendo adotadas desde os anos 1990, mas com resultados limitados. Mais recentemente, sob a liderança do primeiro ministro Shinzo Abe, um programa macroeconômico de grandes proporções foi lançado. O Abenomics, como é conhecido, apresenta-se em três esferas: monetária, fiscal e estrutural. Sob o slogan Japan is Back!, o governo almeja, em um período de 10 anos, alcançar um crescimento anual real do PIB e da produtividade do trabalho de $2 \%$. Também deseja reascender a confiança empresarial e quebrar o excessivamente prolongado ciclo vicioso de estagnação. O que é distintivo da proposta é a sua audácia, como observado pela meta de dobrar a base monetária ao longo de dois anos e garantir uma meta de inflação de $2 \%$ ao ano (Gráfico 1). A definição de patamares expansionistas claros visa promover o ajuste das expectativas, condição importante para a recuperação (IMF 2013).

Em um primeiro momento, a política expansionista elevou tanto o nível de confiança da indústria como o índice da bolsa Nikkei, que acumulou elevação de $57 \%$ em 2013. Na primeira metade do mesmo ano, quando do lançamento do programa, a taxa anualizada de crescimento do produto chegou a $4 \%$. Entre dezembro de 2012 e dezembro de 2014, a base monetária foi ampliada em $224 \%$. A expansão monetária, ao implicar desvalorização da moeda, tende também a favorecer as exportações.

Do ponto de vista fiscal, o parlamento japonês aprovou um estímulo da ordem de 1,4\% do PIB para o período compreendido entre 2013-2014, além de oferecer incentivos tributários à formação bruta de capital fixo (IMF 2013; Japan 2013). Em contraponto, no entanto, o programa previa um ajuste fiscal a ser obtido por um aumento do imposto sobre consumo, a ser lançado em duas fases. A primeira, em abril de 2014, elevou o dito imposto de 5\% para 8\%; a segunda, 
Gráfico 1 - Base Monetária (final do perído)

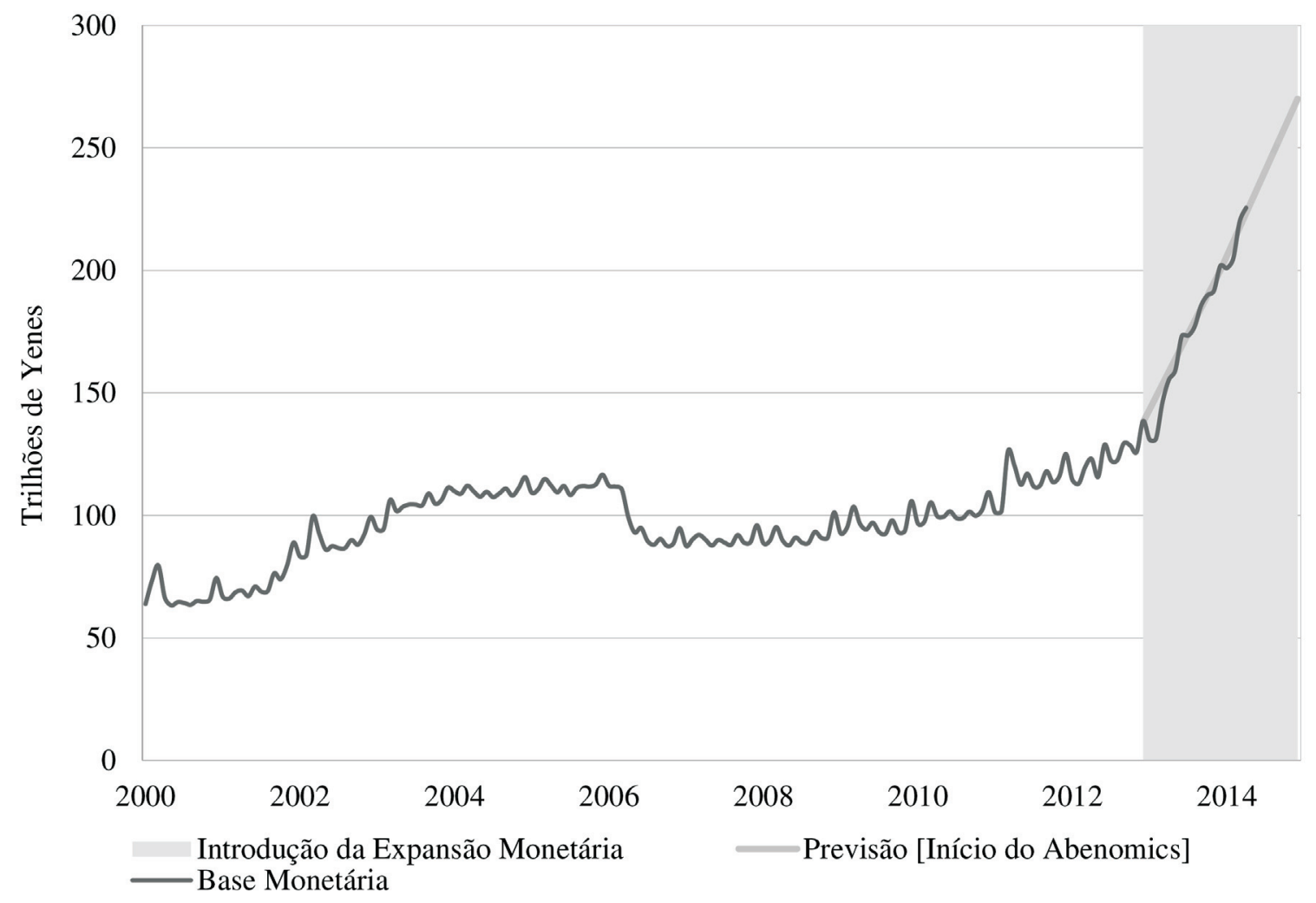

Fonte: Os autores, a partir de Boj (2014), Kuroda (2013) e OCDE (2013).

prevista para outubro de 2015, acrescentar-lhe-á ainda dois pontos percentuais. Argumenta-se que essa elevação teria desestimulado a demanda e contribuído para frustrar a recuperação econômica a partir do segundo semestre de 2014. A meta de aumento inflacionário, por sua vez, passou a ser prejudicada pela redução do preço do petróleo.

O Abenomics pretende também abranger o âmbito estrutural, visando, entre os objetivos, reformar setores, ampliar a flexibilidade do mercado de trabalho e promover a maior abertura da economia. Um dos objetivos é reformar o setor agrícola, caracterizado por altíssimas taxas de proteção e por subsídios governamentais que respondem por 50\% da receita líquida do setor (OECD 2013). Para isso, o plano econômico prevê incentivos para acelerar a concentração da propriedade rural e tornar o setor mais competitivo, o que implica medidas para a desregulamentação do arrendamento da terra e para o fortalecimento da infraestrutura (Japan 2013). Há de se observar, no entanto, a dificuldade de fazer reformas em um setor cujo apoio político é tão caro para o LDP.

Outro setor problemático é o de energia. O Japão tem, em sua matriz energética, uma baixa participação de fontes renováveis e uma elevada dependência da energia nuclear. Seu custo energético está entre os mais elevados do mundo desenvolvido, com o MWh custando mais do dobro do norte-americano (OECD 2013). O acidente nuclear de Fukushima, ao gerar o fechamento de muitas usinas, agravou a situação. Apesar de o setor energético entrar na pauta de reformas do plano de revitalização, há a proeminência do carvão e da energia nuclear como fontes de eletricidade (Suga \& Watanabe 2014). 
Um ponto central diz respeito ao sistema de inovação. A sofisticação da atividade empresarial e o desempenho do sistema de inovação são fatores-chave na competitividade do Japão, que continua a ter resultados muito favoráveis em vários indicadores de inovação. Em termos de pedidos de patentes, por exemplo, só perde para os Estados Unidos, estando bem à frente do terceiro colocado. As inovações se dão em grande parte no topo da cadeia de valor, com produtos de alto valor agregado. Não obstante, o sistema de inovação também sofre críticas. Argumenta-se que o sistema, muito favorável ao catching up tecnológico até a década de 1970, não respondeu bem à onda tecnológica subsequente e à emergência de novos setores (Lechevalier 2011). Apesar de medidas recentes voltadas a promover pequenas empresas inovadoras e a favorecer o empreendedorismo nas universidades, Lechevalier (2011) argumenta que o modelo continua muito centrado na inovação incremental, sendo os setores mais fortes o eletrônico, o automobilístico e o de máquinas e equipamentos. Há um pioneirismo no segmento de robótica pessoal e de videogames, porém um atraso relativo nos setores de nanotecnologia, meio-ambiente e desenvolvimento de software.

Segundo análise do Fórum Econômico Mundial (WEF 2014), o Japão é a sexta economia mais competitiva do mundo. Não obstante, há um forte contraste no seu desempenho em diferentes indicadores de competitividade. Os desafios macroeconômicos, a participação feminina no mercado de trabalho e a dificuldade em contratar e demitir são aspectos em que o Japão apresenta um dos piores resultados entre os países da OECD. Notadamente, a pesada tributação imposta à pessoa jurídica, as barreiras tarifárias, o relativo isolamento e a elevada burocracia para a criação de novos negócios constituem grandes entraves. Em uma análise sobre a facilidade de abrir uma empresa, conforme ranking da Doing Business (DB 2014), o Japão se enquadra na $120^{\mathrm{a}}$ posição mundial. Além disso, o país tem uma das mais altas taxas de impostos para empresas entre os países membros da OECD (Mooij \& Saito 2014).

O governo japonês vem também defendendo maior abertura da economia, incentivando o investimento direto no exterior e buscando acordos de livre comércio, notadamente o TPP (Trans-Pacific Partnership). O Japão assinou um tratado de livre comércio com a Associação de Nações do Sudeste Asiático (ASEAN), assim como fizeram a China e a Coreia do Sul. No entanto, a possibilidade de um grande acordo de livre comércio envolvendo os três países é considerada pouco provável, devido à resistência dos respectivos setores domésticos (Corning 2011). Segundo Ueno e Yamano (2014), os acordos comerciais do Japão respondiam por 17\% das exportações, sendo necessário fortalecê-los e abrir mais o país. As lideranças favoráveis às reformas veem os tratados como forma de avançar nas mudanças consideradas necessárias.

Outra área considerada prioritária é o mercado de trabalho, com os objetivos de promover maior flexibilidade e melhorar a inserção da mulher. O discurso de mudança é evidente, como mostra a citação abaixo feita pelo gabinete do primeiro ministro: "o sistema de emprego vitalício, em que os jovens se formam, encontram emprego e trabalham na mesma empresa até a aposentadoria é agora coisa do passado" (Japan 2013, p.6; tradução livre). No entanto, essa é uma das áreas mais criticadas do Abenomics, dado que pouco vem sendo feito para reverter as dificuldades. A situação das mulheres tem em muitos casos se agravado, uma vez que têm despendido tempo crescente em serviços de cuidado aos filhos e idosos, em detrimento da carreira profissional (Kelly \& White 2002). Enfim, as reformas propostas pelo Abenomics incluem outras áreas, como sistema de saúde e mudanças na governança corporativa. No entanto, muito do que se chama de reforma estrutural tem ficado na retórica e a impressão é que não se sabe muito bem o que se reformar e como fazê-lo (Jones 2014). 
De uma forma geral, muito do impacto observado até então é apenas de curto prazo, em virtude do estímulo monetário. Este, como destacado, também tem sido colocado em dúvida, fruto dos efeitos negativos do aumento dos impostos e das dificuldades de atingir a meta inflacionária. Segundo Pilling (2015), no entanto, é necessário não ser muito pessimista. A queda recente no preço do petróleo, ao reduzir os custos e melhorar o poder de compra, tende também a fortalecer o consumo. O mercado de trabalho também tem estado aquecido, havendo evidência de oferta de melhores condições de trabalho para muitos trabalhadores irregulares, o que tende a fortalecer o potencial para o consumo. Como conclui Pilling (2015), embora seja prematuro declarar a vitória do Abenomics, é preciso também enfatizar que "o programa não está morto e enterrado".

\section{Conclusões}

No período de recuperação do pós-guerra, procurou-se difundir a ideia do Japão como uma grande família. As firmas eram definidas como grandes comunidades, marcadas pelos valores de lealdade e comprometimento mútuo. Além disso, o modelo era admirado pelas relações de trabalho mais democráticas. As práticas de emprego vitalício e as relações de longo prazo com bancos e fornecedores indicavam alternativas ao capitalismo desregulado e mais sensível às flutuações de mercado.

Em face das dificuldades atuais, tem sido difícil defender algumas dessas associações. Há grande frustração com um modelo que, apesar de ter produzido um país rico, vem sendo incapaz de oferecer oportunidades para um número crescente de pessoas. Uma grande fonte de dificuldades decorre de mudanças no mercado de trabalho, influenciadas pelo menor fôlego do emprego industrial e pela exportação de parte desses empregos, a qual se soma os efeitos da crise. Como resultado, a oferta de emprego tem sido pouco dinâmica e, em face da acirrada competição, o acesso às vagas de emprego tem se tornado fortemente correlacionado com o tipo de escola a que o jovem tem acesso. Em outras palavras, a chance de se conseguir um emprego tornou-se muito correlacionada com a situação econômica da família e com a possibilidade de pagar pela educação de melhor qualidade, comprometendo a associação entre as chances de ascensão social e o mérito.

O emprego temporário tornou-se a opção mais provável para a maior parte dos indivíduos que ingressam no mercado de trabalho, com poucas chances de que venham a obter um emprego permanente. $\mathrm{O}$ uso crescente de trabalhadores temporários produz grandes diferenças internas às empresas e torna mais difícil a associação da firma a uma grande família. Outra dificuldade diz respeito às mulheres. A divisão do trabalho entre os sexos no Japão era muito pronunciada, cabendo aos homens o acesso aos principais empregos e às mulheres as funções domésticas e/ou o acesso a empregos temporários, visando equilibrar a renda familiar. Essa situação se modificou em função de mudanças culturais e na estrutura das famílias. Há um número crescente de mulheres adiando o casamento e vivendo mais tempo com os pais. Estas encontram, no entanto, grandes dificuldades de obter um emprego de qualidade (Kelly \& White 2002).

Em face dos custos educacionais crescentes, as mulheres têm se engajado cada vez mais em empregos temporários com o intuito de financiar a educação dos filhos. No entanto, vêm se dedicando crescentemente aos serviços de cuidado a pais e sogros, resultado do envelhecimento da população e do atraso das instituições de seguridade social. Constitui-se um impasse: a mulher precisa trabalhar para ajudar nas despesas domésticas, mas precisa também dedicar-se aos parentes idosos. Apesar da criação de centros públicos de cuidado para crianças e idosos e do crescimento de ONGs prestando esses serviços, a oferta é 
muito limitada. Assim, o caso japonês aparece como o reverso do escandinavo, em que a ampla oferta de serviços públicos estimula tanto a maternidade como a participação da mulher no mercado de trabalho.

O que se nota no Japão é, portanto, uma enorme rigidez na estrutura social, com grande dualismo entre insiders e outsiders. Um grupo relativamente grande de pessoas, os mais velhos e aqueles que possuem um emprego regular, tem passado relativamente ileso pela crise. Aqueles que construíram a vida profissional nos tempos de prosperidade e possuem aposentadoria encontram-se em boa situação (Kaji 2015). Do outro lado, há os perdedores, principalmente os jovens e mulheres com poucas chances de conseguir empregos permanentes. Os perdedores sofrem em silêncio, dado que não há manifestações políticas e outras formas de protesto. Além disso, os jovens tendem a ter baixa taxa de participação nas eleições, o que contribui para o baixo envolvimento dos políticos com suas causas. Isso ajuda a explicar um dos pontos mais preocupantes do processo, o fato de, apesar da exclusão crescente, não se consolidar um programa alternativo de reformas. Os grupos insatisfeitos são incapazes de se organizar e suas frustrações não têm chegado devidamente ao sistema político.

A situação econômica é igualmente desalentadora. O Japão ilustra uma enorme dificuldade do capitalismo em termos macroeconômicos, gerando grande receio por parte de outros países de que possam vir a se "contaminar" pela "doença japonesa". Em face do envelhecimento da população, das dificuldades fiscais e de outros desdobramentos, o país não consegue se recuperar. O ponto é bem captado por Gamble (2014, p.141), que sugere que a situação japonesa tende a contribuir para entender os impasses pós o crash de 2018: "Japan became locked into a cycle of low growth and deflation which proved very hard to break. It was still one of the largest and richest economies in the world. It did not suffer a major slump or social collapse; but it did not grow very much either. It is often cited as an example of what could happen to other western economies in this new period after the crash. They might suffer the same fate as Japan: a long period of slow deleveraging, weak growth and depressed demand".

Nesse contexto, a falta de um estado de bem-estar social (EBS) abrangente tende a ser parte do problema, dado que o EBS, ao prover mecanismos anticíclicos de estímulo à demanda e garantir a aposentadoria, tenderia a estimular o consumo. Além disso, o EBS contribuiria para a melhor situação das mulheres e para a maior participação no mercado de trabalho.

A despeito da crise duradoura, há ainda divergências sobre o diagnóstico e sobre o que fazer para recuperar a economia. Isso é bem ilustrado pelo debate sobre a relação entre instituições e desempenho econômico. Em face das novas configurações internacionais, é essencial que o Japão flexibilize parte de suas práticas e instituições, assim como adote medidas para reduzir o custo de se fazer negócios. No entanto, as conclusões são mais complexas (e dúbias) em relação a outras instituições, como a governança corporativa e a relação com os bancos e fornecedores. Embora a economia precise de formas de financiamento mais ágeis, principalmente para o venture capital, as relações de longo prazo com os bancos tendem a continuar a ser úteis. O mesmo se aplica em relação aos fornecedores, sendo que as empresas precisam encontrar um equilíbrio entre a necessidade de usar o mercado e reduzir os custos e o papel das relações de longo prazo para a geração de qualidade do produto e inovação.

Há também claros efeitos positivos nas relações de longo prazo com os trabalhadores, uma vez que contribuem para a qualidade da força de trabalho e para a consolidação de vantagens comparativas em produtos de alta qualidade (Hall \& Soskice 2001). Entretanto, algo tem de ser feito para reduzir o dualismo do mercado de trabalho. Acredita-se que a recuperação econômica, junto com 
os efeitos demográficos que retiram anualmente centenas de milhares de pessoas do mercado de trabalho, possa contribuir. Não obstante, é também essencial a adoção de medidas que ampliem direitos e reduzam as distâncias entre os dois grupos de trabalhadores.

Em síntese, embora seja fundamental rejuvenescer o modelo e recuperar a economia, é necessária cautela em relação às conclusões sobre a relação entre as instituições do modelo japonês e o desempenho econômico. Para um grupo de economistas e cientistas sociais, as características institucionais, fruto de interesses e práticas consolidadas, emperram a recuperação da economia. Para outro, as instituições têm seu potencial e o mostraram historicamente: a crise é vista principalmente como macroeconômica e, uma vez equacionada e realizados os ajustes necessários, incluindo no campo internacional, as instituições podem ajudar o Japão a enfrentar os novos desafios, inclusive os sérios desafios fiscal e demográfico. A partir da ampla bibliografia consultada em anos de pesquisa, não é possível concluir enfaticamente em relação a uma ou outra posição, assim como não se pode precisar qual será a configuração futura do modelo japonês. No curto e médio prazo, o modelo continuará a apresentar características híbridas e próprias, sem haver convergência em direção a um modelo liberal.

Alexandre Queiroz Guimarães (alexandre.queiroz@fjp.mg.gov.br) é Doutor em Ciência Política e Economia Política pela Universidade de Sheffield (Reino Unido), e professor da Escola de Governo da Fundação João Pinheiro. Vínculo institucional: Escola de Governo da Fundação João Pinheiro, Belo Horizonte, MG, Brasil.

André Mourthé de Oliveira (demourthe@gmail.com) é Doutor em Desenvolvimento Econômico pela Universidade Estadual de Campinas (Unicamp) e professor do Departamento de Ciências Econômicas e Gerenciais da Universidade Federal de Ouro Preto (UFOP). Vínculo institucional: Departamento de Ciências Econômicas e Gerenciais (DECEG), UFOP, Ouro Preto, MG, Brasil.

Rafael Teixeira Dias Camargos (rafaeltdcs@gmail.com) é Bacharel em Ciências Econômicas pela Pontifícia Universidade Católica de Minas Gerais (PUC-Minas) e Mestrando em Economia no Departamento de Economia da Universidade Federal de Viçosa (UFV). Vínculo institucional: Departamento de Economia, UFV, Viçosa, MG, Brasil.

Paulino Oliveira Neto (paulino.oliveira@nyu.edu) é Pós-Graduado em Comércio Internacional pelo Instituto Brasileiro de Mercado de Capitais (Ibmec) de Belo Horizonte e Mestrando em Engenharia Financeira pela New York University (EUA). Vínculo institucional: Department of Finance and Risk Engineering, New York University, Nova York, NY, Estados Unidos.

\section{Referências}

Aronson, B.E., 2011. A Reassessment of Japan's Big Bang Financial Regulatory Reform. IMES Discussion Paper Series, 19 , pp.1-38.

Boltho, A. \& Corbett, J., 2000. The Assessment: Japan's Stagnation: Can Policy Revive the Economy? Oxford Review of Economic Policy, 16(2), pp.1-17. DOI: 10.1093/oxrep/16.2.1

Breslin, S., 2010. Comparative Theory, China, and the Future of East Asian Regionalism(s). Review of International Studies, 36(3), pp.709-729. DOI: 10.1017/s0260210510000665

Coates, D., 2000. Models of Capitalism: Grow and Stagnation in the Modern Era. Cambridge, MA: Polity Press.

Coe, N.M.; Johns, J. \& Ward, K., 2010. Transforming the Japanese Labour Market: Deregulation and the Rise of Temporary Staffing. Regional Studies, 45(8), pp.1091-1106. DOI: 10.1080/00343401003713423

Corning, G.P., 2011. Trade Regionalism in a Realist East Asia: Rival Visions and Competitive Bilateralism. Asian Perspective, 35(2), pp.259-286. DOI: 10.1007/978-1-4020-5951-3_9

Craig, V.V., 1998. Financial Deregulation in Japan. FDIC Banking Review, 11(3). Disponível em: https://www.fdic.gov/bank/analytical/banking/1998fall/japan.pdf. Acesso em: 28 out. 2016.

Ernst, D., 2006. Searching for a New Role in Eat Asian Regionalization: Japanese Production Networks in the Electronics Industry. In P. Katzenstein \& T. Shiraishi, eds. Beyond Japan: The Dynamics of East Asian Regionalism. Ithaca: Cornell University Press.

Fraga, J.S. \& Strachman, E., 2013. Crise financeira: o caso japonês. Nova Economia, 23(3), pp.522-553. DOI: 10.1590/s0103-63512013000300002

GAMBLE, A., 2014. Crisis without end? The unravelling of western prosperity. New York: Palgrave Macmillan. 
Gao, B., 2001. Japan's Economic Dilemma: The Institutional Origins of Prosperity and Stagnation. Cambridge, UK: Cambridge University Press.

Guimarães, A., 2007. O capitalismo coordenado japonês: da bem-sucedida industrialização do pós-guerra à crise dos anos 90 . In VIII Congresso Brasileiro de História Econômica. Aracaju.

Hall, P. \& Soskice, D., 2001. An Introduction to Varieties of Capitalism. In P. Hall \& D. Soskice, eds. Varieties of Capitalism: The Institutional Foundations of Comparative Advantage. Oxford: Oxford University Press.

Hamada, K. \& Okada, Y., 2009. Monetary and International Factors behind Japan's Lost Decade. Journal of the Japanese and International Economies, 23(2), pp.200-219. DOI 10.1016/j.jjie.2009.01.004

Jackson, G., 2001. The Origins of Nonliberal Corporate Governance in Germany and Japan. In W. Streeck \& K. Yamamura, eds. The Origins of Nonliberal Capitalism: Germany and Japan in Comparison. Ithaca: Cornell University Press.

Jackson, G. \& Moerke, A., 2005. Continuity and Change in Corporate Governance: Comparing Germany and Japan. Corporate Governance: An International Review, 13(3), pp.351-361. DOI: 10.1111/j.1467-8683.2005.00429.x

Jacoby, S., 2007. The Embedded Corporation: Corporate Governance and Employment Relations in Japan and the United States. Princeton: Princeton University Press.

Jones, R., 2014. Japan: Making the Comeback Last. OECD Observer. Disponível em: http://issuu.com/oecd.publishing/docs/oecd_observer_japan_50th_anniversar. Acesso em: 28 out. 2016.

Johnson, C., 1982. MITI and the Japanese Miracle: The Growth of Industrial Policy, 1925-1975. Stanford: Stanford University Press.

, 1998. Economic Crisis in East Asia: The Clash of Capitalisms. Cambridge Journal of Economics, 22(6), pp.653-661.

Kang, K.; Syed, M. \& Tokuoka, M., 2009. Revisiting Japan's Lost Decade. In International Monetary Fund, ed. Asia and Pacific Regional Economic Outlook. Washington: IMF.

Kelly, W. \& White, M., 2006. Students, Slackers, Singles, Seniors, and Strangers: Transforming a Family-Nation. In P. Katzenstein \& T. Shiraishi, eds. Beyond Japan: The Dynamics of East Asian Regionalism. Ithaca: Cornell University Press.

Lechevalier, S., 2011. La convergence vers le modèle de la Silicon Valley est-elle la seule voie possible pour le système d'innovation japonais? In __ _ La grande transformation du capitalisme japonais (1980-2010). Paris: Presses de Science Po.

MacKinnon, R. \& Ohno, K., 2001. The Foreign Exchange Origins of Japan's Economic Slump and Low Interest Liquidity Trap. The World Economy, 24(3), pp.279-315. DOI: 10.2139/ssrn.1009485

Miyajima, H., 2012. Institutional Change and its Economic Consequence in Japan: The Bright and Dark Sides of Hybridization. RIETI Discussion Paper Series, 12(049).

Mooij, R.D. \& Saito, I., 2014. Japan's Corporate Income Tax: Facts, Issues and Reform Options. IMF Working Paper, 14(138).

Pempel, T.J., 1998. Regime Shift: Comparative Dynamics of the Japanese Political Economy. Ithaca \& London: Cornell University Press.

, 2006. A Decade of Political Torpor: When Political Logic Trumps Economic Rationality. In P. Katzenstein \& T. Shiraishi, eds. Beyond Japan: The Dynamics of East Asian Regionalism. Ithaca: Cornell University Press.

Sako, M. \& Kotosaka, M., 2011 Continuity and Change in the Japanese Economy: Evidence of Institutional Interactions in Financial and Labour Markets. In A. Walter \& X. Zhang, eds. East Asian Capitalism: Diversity, Continuity and Change. Oxford: Oxford University Press.

Suzuki, H., 2010. Employment Relations in Japan: Recent Changes under Global Competition and Recession. Journal of Industrial Relations, 52(3), pp.387-401. DOI 10.1177/0022185610365647

Uchida, H.; Udell, G.F. \& Watanabe, W., 2007. Bank Size and Lending Relationships in Japan. NBER Working Paper Series, WP 13005.

Ueno, A. \& Yamano, N., 2014. Trade: Not Just Made in Japan. OECD Observer, April. Disponível em: http://issuu.com/oecd.publishing/docs/oecd_observer_japan_50th_anniversar. Acesso em: 28 out. 2016.

Vogel, S., 2006. Japan Remodeled: How Government and Industry Are Reforming Japanese Capitalism. Ithaca \& London: Cornell University Press.

\section{Artigos em jornais}

Kaji, S., 2015. Japan's Economic Losers Suffer in Silence. Financial Times, 10 Mar.

Pilling, D., 2015. Lucky Has Bought a Little Time for Abenomics. Financial Times, 12 Mar.

Suga, M. \& Watanabe, C., 2014. Após Fukushima, Japão prefere carvão à energia renovável. Exame.com. Disponível em: http://exame.abril.com.br/mundo/noticias/apos-fukushima-japao-prefere-carvao-a-energia-renovavel. Acesso em: 28 out. 2016.

\section{Outras fontes}

Bank of Japan, 2014. Monetary Base: Long-Term Time-Series Data. Disponível em: http://www.boj.or.jp/en/statistics/boj/other/mb/mblong.zip. Acesso em: 28 out. 2016.

IMF, 2013. Japan: The 2013 Article IV Consultation. Disponível em: https://www.imf.org/external/pubs/ft/scr/2013/cr13253.pdf. Acesso em: 28 out. 2013. 
Japan. Prime Minister of Japan and His Cabinet, 2013. Japan Revitalization Strategy: Japan is Back. Disponível em: http://www.kantei.go.jp/jp/singi/keizaisaisei/pdf/en_saikou_jpn_hon.pdf. Acesso em: 28 out. 2016.

OECD, 2013. Japan: Towards a New Dynamic Growth. Highlights from the 2013 OECD Economic Survey of Japan. Disponível em: http://www.oecd.org/japan/2013.04_Japan_Brochure_EN.pdf. Acesso em: 28 out. 2016. , 2015. Principais Indicadores Econômicos.

WEF, 2014. The Global Competitiveness Report 2014-2015: Full Data Edition. Disponível em: http://www3.weforum.org/docs/WEF_GlobalCompetitivenessReport_2014-15.pdf. Acesso em: 28 out. 2016.

The World Bank, 2014. Ease of Doing Business in Japan. In __. Doing Business. Disponível em: http://www.doingbusiness.org/data/exploreeconomies/japan/. Acesso em: 28 out. 2016. 


\title{
Institutions and development in Japan: model of capitalism, post-1990 trajectory, current challenges
}

\begin{abstract}
The article is concerned with the change of trajectory of the Japanese economic model. It intends to understand why a model which was very successful in the decades from 1950 to 1980 has faced serious difficulties since the 1990s. The article explores the inter-relations between institutional, economic and political factors, giving special attention to the institutions which were typical of the Japanese model of capitalism, including labor relations, corporate governance, organization of the financial system and the role of the state. It emphasizes the role played by those institutions in the phase of prosperity, but also the pressures which they came to suffer in result of international and domestic transformations. A key aspect is to evaluate the degree in which the Japanese model is still able to preserve the features typical of a "coordinated market capitalism". The article employs a political economy approach centred on historical institutionalism and varieties of capitalism theories. This approach, showing how domestic institutions condition national responses, offers a powerful referential to interpret the changes and increases our understanding about the interactions among institutions, politics and the economy. Besides historical institutionalism, the article employs specific theories to understand the economic crisis and other challenges faced by the Japanese economy. The article finds that Japan has been facing many institutional changes, but has also preserved many features of its traditional model. The result is the emergence of a hybrid model. In addition to the macroeconomic problems, related to insufficiency of effective demand, to the aging population and to the fiscal difficulties, Japan has also faced other political and social challenges. They include a dual labor market and few opportunities to women and young people. In face of all these challenges, the political system has failed to offer a package of reforms. In brief, the effort to explore different dimensions permits a wide comprehension of many challenges faced by Japanese economy and society.
\end{abstract}

KEYWORDS: varieties of capitalism; Japan; institutions; comparative political economy; comparative development.

This is an Open Access article distributed under the terms of the Creative Commons Attribution Non-Commercial License which permits unrestricted non-commercial use, distribution, and reproduction in any medium provided the original work is properly cited. 